\title{
Safety and Tolerability of High Doses of Glucocorticoides
}

\author{
Branislava D. Rakić1,2, Jovanka L. Kolarović ${ }^{3}$, Nada V. Konstantinidis ${ }^{3}$, \\ Velibor S. Čabarkapa ${ }^{4}$, Milan B. Ubavić ${ }^{2}$ Ana J. Sabo ${ }^{5}$, \\ Aleksandar L. Rašković ${ }^{5}$
}

\begin{abstract}
${ }^{1}$ Medical Faculty, Department of Pharmacy, University of Novi Sad
${ }^{2}$ Faculty of Pharmacy, University Business Academy in Novi Sad, , Novi Sad

${ }^{3}$ Institute for Child and Youth Health Care of Vojvodina, Novi Sad

${ }^{4}$ Department of Patophysiology, Faculty of Medicine, University of Novi Sad

${ }^{5}$ Medical Faculty, Department of Pharmacology, toxicology and clinical pharmacology,

University of Novi Sad
\end{abstract}

\section{SUMMARY}

Introduction: Treatment of acute lymphoblastic leukemia includes the use of high doses of glucocorticoides (prednisone and dexamethasone), which significantly increase the success of therapy due to lymphocytolitic effect.

The aim: The aim of the study was to determine tolerability of high doses of prednisone and dexamethasone in children with acute lymphoblastic leukemia and the structure and the intensity of adverse effects, occurred after application of these medicines.

Subjects and methods: In a prospective study, we analyzed adverse effects of high doses of glucocorticoides in children suffering acute lymphoblastic leukemia treated in the Institute for Child and Youth Health Care of Vojvodina, since December 2010. until October 2014, were analyzed. This study included 18 patients, aged from 2 to 15 years.

Results: Hyperglycemia appeared in $89 \%$ of patients treated with prednisone and in $61 \%$ of patients treated with dexamethasone. In order to control the high blood glucose level (above $10 \mathrm{mmol} / \mathrm{L}$ ), in $11 \%$ of patients insulin was used. Hypertension appeared in $28 \%$ patients treated with prednisone and dexamethasone. Antihypertensives were needed for regulation in $17 \%$ patients. Hypopotassemia and hypocalcaemia were significantly more expressed after the use of prednisone in comparison to dexamethasone. In $11 \%$ of patients, the treatment with dexamethasone caused depressive behavior, followed by agitation.

Conclusion: Adverse effects of dexamethasone and prednisone, administered in high doses in children with ALL were known, expected and reversible. Adverse reactions usually disappeared spontaneously or after short-term symptomatic therapy.

Keywords: prednisone, dexamethasone, acute lymphoblastic leukemia, adverse effects, children 


\section{INTRODUCTION}

Acute lymphoblastic leukemia (ALL) is one of the most common malignancy in children and adolescents. It is a disease that occurs by malignant clonal proliferation of transformed lymphoid progenitors (leukemic lymphoblasts) that accumulate in the bone marrow, lymph nodes, liver, spleen and other organs [1]. The most common symptoms are fatigue and lethargy, fever, pain in bones and joints. Synthetic steroids, prednisone and dexamethasone, represent part of ALL treatment in children [2]. The treatment of ALL is based on the protocol of Berlin-Frankfurt-Munster group (BFM) and has four phases. Prednisone applies in the first phase, while dexamethasone applies in second or in the third phase of the treatment [3]. Compared with natural glucocorticoids, synthetic glucocorticoids have stronger pharmacological activity. By changing the structure (adding fluorine atoms in the molecule) mineralocorticoid adverse effect is decreased. Glucocorticoid administration increases the number of circulating neutrophils, and reduces the number of lymphocytes ( $T$ and $B$ ), monocytes, eosinophils and basophils. A larger number of neutrophils is caused by their increased migration from the bone marrow, and also because of the reduced passage through the capillaries. This leads to the reduction of the number of neutrophils in the place of inflammation [4]. In comparison to prednisone, dexamethasone has better penetratation to the blood-brain barrier and into the bone marrow, resulting in a better therapeutic outcome (lower rate of relapse in the CNS and bone marrow). Some adverse effects of dexamethasone are stronger compared to the prednisone, but both glucocorticosteroids are used as part of the treatment protocol for leukemia [5-8]. Common side effect of systemic administration of glucocorticoids is suppression of the adrenal cortex, which occurs by inhibition of corticotropin (ACTH) secretion. This is particularly evident if the therapy is administered over the long period of time (more than 7 days) and if it is abruptly stopped. Prevention of this adverse effect is achieved by a gradual dose reduction of these drugs [2]. Iatrogenic Cushing's syndrome is also an adverse effect of glucocorticoid therapy. Due to the mineralocorticoid activity, usage of glucocorticoids leads to metabolic disorders of water and electrolytes, which result in water retention, hyponatremia, hypokalemia and hipochloremic alkalosis and high blood pressure. This side effects can limit the usage of these drugs [2,3]. Glucocorticoids stimulate gluconeogenesis and glycogenolysis which can cause iatrogenic diabetes mellitus. Muscle weakness, loss of muscle mass and osteoporosis with concomitant risk of fractures are also common consequences of their application. Glucocorticoids inhibit release of growth hormone (even if it is administered in lower doses). Mental disorders such as euphoria, depression, psychosis, agitation and suicide, are also observed during the treatment of glucocorticoids [3,9]. Glucocorticoids can cause a peptic ulcer disease due to the inhibition of arachidonic acid metabolism and prostaglandins, which protect mucous membrane in the stomach and duodenum from hydrochloric acid and bile salts [3]. By suppressing of cellular immunity, glucocorticoids increase the tendency to fungal and viral infections $[2,3,9]$. Considering that the administration of glucocorticoids significantly increased therapeutic efficiency of the protocol for the treatment of acute lymphoblastic leukemia in children potential toxicity of treatment is very important. The aim of this study was to analyze the adverse effects of high doses of corticosteroids in these patients.

\section{SUBJECTS AND METHODS}

Children aged 2 to 15 ( 9 boys and 9 girls) all treated according to the German BFM protocol in period from December 2010 to October 2014 were included in this observational prospective study upon having their parents' consent. The patients were treated in the Institute for Child and Youth Health Care of Vojvodina. Consent was obtained by the Ethics Committee of the Institute for Child and Youth Health Care.

Prednison is administered during the first part of the induction phase (Protocol IA) with vincristine, daunorubicin and $\mathrm{L}$ asparaginase. Prednisone is given orally, $60 \mathrm{mg} / \mathrm{m} 2 / \mathrm{d}$, in 3 single doses from days 1-37. Prednison is introduced gradually $(25 \%, 50 \%, 75 \%, 100 \%$ of total dose during first four days) and it is tapered from days 29-37 by reducing the dose for $50 \%$ on every third day. Vincristine was administered as i.v. bolus at dose of $1.5 \mathrm{mg} /$ $\mathrm{m} 2 / \mathrm{d}$ (maximal singe dose $2 \mathrm{mg}$ ), concomitantly with daunorubicin $30 \mathrm{mg} / \mathrm{m} 2 / \mathrm{d}$ given as 1 hour infusion on day: $8,15,22,29$. E. coli 
$\mathrm{L}$-asparaginase is given as intramuscular injection at dose of $5,000 \mathrm{U} / \mathrm{m} 2 / \mathrm{d}$, on day: 12 , $15,18,21,24,27,30,33$ (8 doses). Dexamethason is administered during the first part of the reinduction phase (Protocol II/1) with vincristine, doxorubicin and $\mathrm{L}$ asparaginase. Dexamethasone $10 \mathrm{mg} / \mathrm{m} 2 / \mathrm{d}$, is given orally or intravenously in 3 single doses, on day: $1-21$. By day 22 taper down stepwise to withdrawal over 9 days by halving the dose every 3 days, giving the highest dose in the morning. Vincristine was administered as iv bolus at dose of $1.5 \mathrm{mg} / \mathrm{m} 2 / \mathrm{d}$ (maximal singe dose $2 \mathrm{mg}$ ), concomitantly with doxorubicin $30 \mathrm{mg} / \mathrm{m} 2 / \mathrm{d}$ given as 1 hour infusion on day: $8,15,22,29$. E. coli L-asparaginase is given as intramuscular injection at dose of $10000 \mathrm{U} / \mathrm{m} 2 / \mathrm{d}$, on day: 8 , $11,15,18$ (4 doses). Dexamethason at dose 20 $\mathrm{mg} / \mathrm{m} 2 / \mathrm{d}$ (days 1-6) is given as part high dose chemotherapy blocks containing vincristine at standard, previously mentioned dose, high dose methotrexate $5 \mathrm{~g} / \mathrm{m} 2$ in 24 hour infusion on day 1, cyclophosphamide $200 \mathrm{mg} / \mathrm{m} 2 / \mathrm{d}$ over 1 hour infusion, 5 doses 12 hour apart on day: $2-4$ and high dose cytarabine $(2 \mathrm{~g} /$ $\mathrm{m} 2$, two doses 12 hours apart on day 5). Blood pressure, psychologists' opinion and course of the disease were analyzed from the medical records of patients during the period of application of corticosteroids. The concentration of glucose, sodium, potassium, calcium, urea and creatinine in serum, as well as alanine aminotransferase (ALT), aspartate aminotransferase (AST), gamma-glutamyl transferase (GGT) levels were analyzed as well.

\section{RESULTS}

Administration of glucocorticoids in children diagnosed with ALL caused the impairment in glucose regulation. Graph 1 shows the incidence of hyperglycemia after administration of prednisone and dexamethasone. Hyperglycemia occurred in 17 patients during administration of prednisone and in 11 patients during administration of dexamethasone. In 2 patients glucose blood level was higher than 10 $\mathrm{mmol} / \mathrm{L}$ (which occurred during the application of dexamethasone) therefore insulin was administered.

High blood pressure (graph 2) was found in 5 patients during administration of prednisone and dexamethasone. The values of high blood pressure were within the range of $130 / 90$ to $165 / 110 \mathrm{mmHg}$ (according to

\section{The incidence of hyperglycemia}

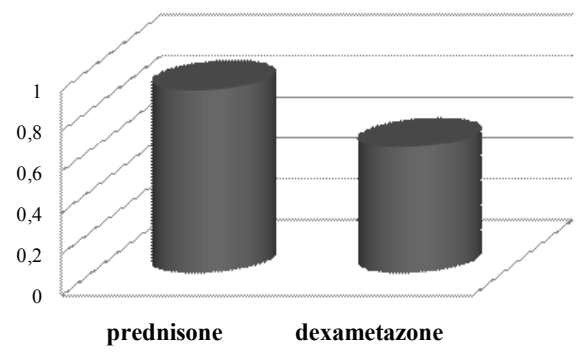

the criteria for the classification of hypertension according to the age of the child). In 3 patients, antihypertensive drugs (nifedipine, spironolactone and captopril) were applied. Spironolactone was applied to patient with hypertension and hypopotassemia.

\section{The incidence of hypertension}

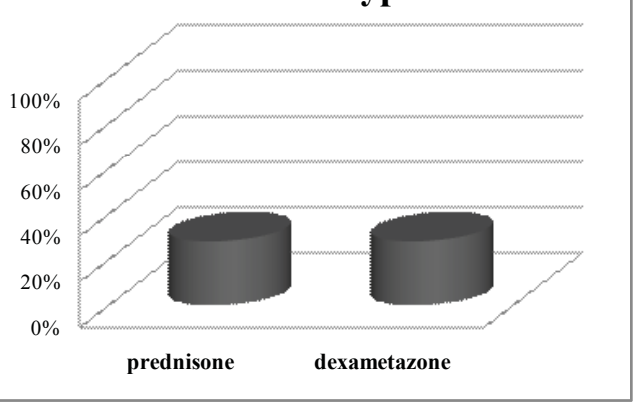

The concentration of C-reactive protein (CRP) increased in 14 patients after prednisone administration (graph 3) from 9.5 to $238 \mathrm{mg} / \mathrm{l}$, and in 9 patients treated with dexamethasone from 14.7 to $101 \mathrm{mg} / \mathrm{l}$. CRP is one of the laboratory variables that indicates the presence of an infection. Saprophytic microorganism, staphylococcus and Candida species, which proliferated due to impairment of the immune system, were isolated in patients, and ceftriaxone, amikacin and fluconazole were administered.

\section{The frequency of increased CRP level}

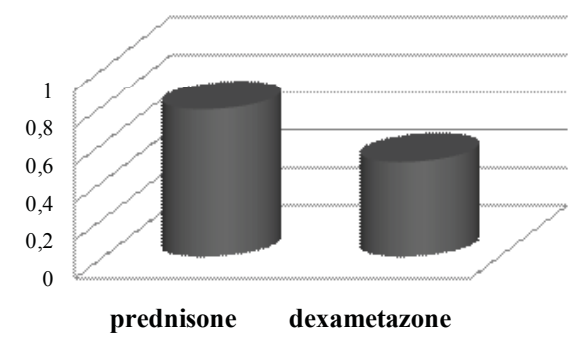

Graph 1. The incidence of hyperglycemia after the application of prednisone and dexamethasone in children with acute lymphoblastic leukemia

Graph 2. The incidence of hypertension after application of prednisone and dexamethasone in children with acute lymphoblastic leukemia

Graph 3. The frequency of increased CRP level after application of prednisone and dexamethasone in children with acute lymphoblastic leukemia 
Graph 4. The incidence of lower concentrations of potassium, sodium and calcium after application of prednisone and dexamethasone in children with acute lymphoblastic leukemia

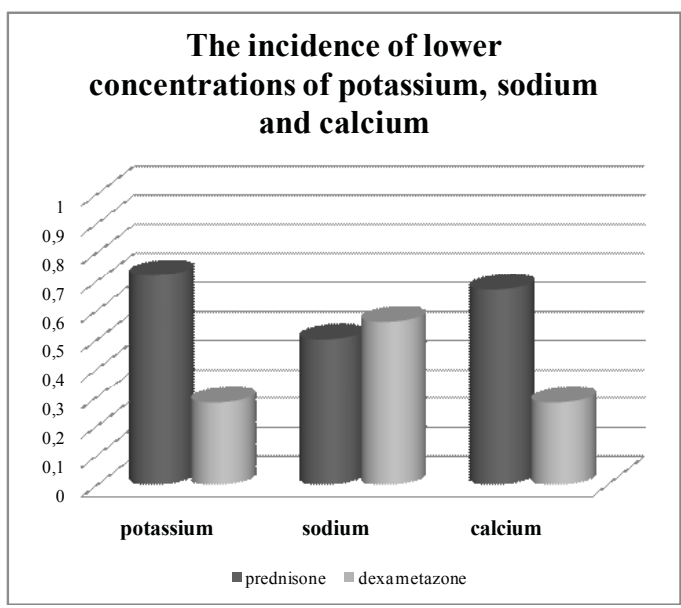

Prednisone has lowered the concentration of potassium in 13 patients, whereas the usage of dexamethasone reduced this concentration in 5 patients (graph 4), and the value of this electrolyte were lower than $4 \mathrm{mmol} / \mathrm{L}$. Hyponatremia, with values below $133 \mathrm{mmol} / \mathrm{L}$, was observed in 9 patients during administration of prednisone, or in 10 patients during the application of dexamethasone. Prednisone reduced the concentration of calcium in 12 patients and dexamethasone in 5 patients (decreased values of calcium ranged from 1.3 to $2.13 \mathrm{mmol} / \mathrm{L}$ ).

Prednisone has increased alanine aminotransferase (ALT) activity with an average value of $3.23 \mu \mathrm{kat} / \mathrm{L} \pm 4.20$ and dexamethasone has also incerased ALT with an average value of $2.86 \mu \mathrm{kat} / \mathrm{L} \pm 2.26$. This represents a 3.8 and 3.4 times higher values as compared to the upper reference value. In patients treated with prednisone and dexamethasone, an increase of aspartate aminotransferase (AST) in serum was also observed. The increase of AST activity after the administration of prednisone was $1.74 \mu \mathrm{kat} / \mathrm{L} \pm 1.61$ (2.9 times higher values), and after the administration of dexamethasone $2.24 \mu \mathrm{kat} / \mathrm{L} \pm 2.07$ (3.7 times higher values). The level of gamma-glutamyltransferase (GGT) was increased during the entire administration of glucocorticoids: $1.58 \mu \mathrm{kat} / \mathrm{L} \pm 3.94$ during prednisone treatment (4.3 times) and $0.77 \mu \mathrm{kat} / \mathrm{L} \pm 0.38$ on dexamethasone therapy (2.1 times).

Prednisone has affected the value of biochemical parameters in serum which indicated changes in renal function. Concentration of urea in serum was increased 1.34 times $(8.08 \mathrm{mmol} / \mathrm{L} \pm 1.17)$, and also concentration of uric acid was increased 1.53 times (452.53 $\mathrm{mmol} / \mathrm{L} \pm 93.34)$. Elevation of values of these biochemical parameters were less during the application of dexamethasone $(6.5 \mathrm{mmol} / \mathrm{L} \pm$ 0 for urea and $352 \mathrm{mmol} / \mathrm{L} \pm 0$ for uric acid). During the application of dexamethasone psychological changes in two patients (one male and one female) were observed. These changes manifested at first with depression, and then with aggression, which occurred after corticosteroids saturate the organism.

\section{DISCUSSION}

The application of high doses of corticosteroids according to the protocols contributes to the success of the therapy because most of the lymphoblast have receptors for glucocorticoids, which prevent their proliferation. Using contemporary protocols for the treatment of ALL in children, about $80 \%$ of patients can be cured, which represents a significant advancement in the treatment of malignant diseases in childhood [10]. Since in these protocols, prednisone and dexamethasone applied in high doses, the incidence of adverse effects in patients were analyzed.

Chronic administration of glucocorticoids is associated with increased risk for glycemic disorders and the occurrence of iatrogenic diabetes. In this study, patients who were treated with prednisone had a higher incidence of reversible hyperglycemia as compared to patients who received dexamethasone. Studies by other authors (Bostrom et al, 2003) suggest that dexamethasone has a greater potential to cause disturbance of glycemic control compared to prednisone [11]. According to the literature, hyperglycemia is usually resolved spontaneously during 48 hours after the treatment with glucocorticoids [12]. In our study, after administration of corticosteroids, hyperglycemia also disappeared spontaneously in $50 \%$ of patients a few days after discontinuation of therapy, but in $11 \%$ of patients insulin was administered.

Due to the mineralocorticoid action, glucocorticoids cause retention of sodium and water in the body, thus the hypertension is rather common $[13,14]$. The data show that hypertensive effect is dose-dependent and high blood pressure occurs in $80 \%$ of patients during corticosteroid therapy $[14,15,16]$. In our study, hypertension occurred in $28 \%$ of patients after the administration of prednisone and dexamethasone. For regulation the high blood pressure (determined by the criteria for 
the classification of hypertension in children), in $17 \%$ of patients antihypertensive drugs (nifedipine, spironolactone and captopril) were applied [17].

Because of the suppressive effect on cellular immunity, prednisone and dexamethasone caused the occurrence of bacterial and fungal infections. These conditions are manifested by febrility, however after the treatment with antibiotics (ceftriaxone and amikacin) and antifungal azoles (fluconazole), disorders had been normalized.

Electrolyte metabolism disorder is expected adverse effect of glucocorticoids $[4,9]$. In this study, the application of prednisone caused a greater decrease in potassium, sodium and calcium level, compared to dexamethasone. These results are explained by the fact that the dexamethasone is fluorinated glucocorticoid and does not have mineralocorticoid activity and electrolyte disturbances are expected more frequently after the application of non-fluorinatedcorticosteroids.

In both BNF (British National Formulary) and Summary of Product Characteristics of the European Medicines Agency (EMA) there is not mentioned an increase in transaminases activity as adverse effect of prednisone and dexamethasone. However, the results of clinical trials, in which prednisone and dexamethasone were administered simultaneously with 6-mercaptopurine and methotrexate, suggest hepatotoxicity and increased activity of liver enzymes, most likely as a consequence of the application of cytostatics [12]. The increase in activity of ALT, AST and GGT obtained in this study, are not typical side effects of antineoplastic drugs used according to the protocol [18-21], but could be explained as result of their concomitant application and interaction with prednisone and dexamethasone, as published in another studies [22,23]. Information in the literature suggest that glucocorticoids may cause disorders of the values of urea and uric acid [9]. In our study both prednisone and dexamethasone increased the concentration of these biochemical parameters. This disorder was more prominent during the application of prednisone, which can be explained with mineralocorticoid effects of this drug and reduction of the excretion of nitrogen compounds.

Agitation and psychological disorders are recognized complications that occur during the application of corticosteroids
$[24,25]$. The authors of clinical studies indicate that females have a higher risk of neurocognitive complications after therapy ALL [26-28], which was not the case in this study-complications were equally represented and in male and female patients. According to the results of other authors, dexamethasone more often causes psychiatric disorders compared to prednisone, primarily due to the greater liposolubility which increased the crossing of blood-brain barrier [29]. In our study, psychological changes in patients were noticed only during the application of dexamethasone. Hostility, withdrawal, agitation, impulsiveness and refusal of contact with family or medical staff were also noticed. Corticosteroids inhibit the metabolism of arachidonic acid and the synthesis of prostaglandins that protect mucous membrane of the gastrointestinal tract, so their application is associated with the development of peptic ulcer disease, the increased gastrin secretion and reduction of protective mucus secretion [30]. Consequently, patients in our study prophylactically obtained $\mathrm{H} 2$ histamine receptor blockers, proton pump inhibitors, and sucralfate. None of the patients did develop peptic ulcer, which is why this prophylaxis is considered very effective.

\section{CONCLUSION}

Dexamethasone and prednisone, administered in high doses in children with acute lymphoblastic leukemia were known and most often disappeared spontaneously after cessation of the treatment with corticosteroids. High doses of prednisone and dexamethasone, as part of the protocol for the treatment of ALL in children, had the greater benefit compared to the risk of adverse reaction.

\section{REFERENCES}

1. Lokadasan R Prem S, Koshy SM, Jayasudha AV. Hypercalcaemia with disseminated osteolytic lesions: a rare presentation of childhood acute lymphoblastic leukaemia. ecancer 2015;9:542 DOI: 10.3332/ ecancer.2015.542.

2. Kadan-Lottick NS, Brouwers P, Breiger D, Kaleita T, Dziura J, Liu H, Chen L, Nicoletti M, Stork L, Bostrom B, Neglia JP. A comparison of neurocognitive functioning in children previously randomized to dexamethasone or prednisone in treatment of childhood acute lymphoblastic leukemia. Blood. 2009;114(9):1746-1752.

3. ALL IC-BF 2009. A randomized Trial of the IBFM- 
SG for the Management

of Childhood non-B acute Lymphoblastic Leukemia, 2009.

4. Varagić V, Milošević M. Farmakologija. Beograd: Elit Medica; 2007 (Serbian).

5. Balis FM, Lester CM, Chrousos GP, Heideman RL, Poplack DG. Differences in cerebrospinal fluid penetration of corticosteroids: possible relationship to the prevention of meningeal leukemia. J Clin Oncol 1987;5:202-207.

6. Jones B, Freeman Al, Shuster JJ, Jacquillat C, Weil M, Pochedly C, Sinks L, Chevalier L, Maurer $H M$, Koch K. Lower incidence of meningeal leukemia when prednisone is replaced by dexamethasone in the treatment of acute lymphoblastic leukemia. Med Pediatr Oncol 1991;19(4):269-275.

7. Mitchell CD, Richards SM, Kinsey SE, Lilleyman J, Vora A, Eden TO. Benefit of dexamethasone compared with prednisolone for childhood acute lymphoblastic leukemia: results of the UK Medical Research Council ALL97 randomized trial. Br J Haematol. 2005;129(6):734-745.

8. Schrappe M, Reiter A, Zimmerman M, Harbott J , Ludwig W-D , Henze G , Gadner H , Odenwald $\mathrm{E}$, Riehm $\mathrm{H}$. Long-term resaults of four consecutive trials in childhood ALL performed by the ALL-BFM study group from 1981 to 1995 . Berlin-FrankfurtMunster. Leukemia 2000;14(12):2205-2222.

9. Rang HP, Dale MM, Ritter JM, Moore PK. Pharmacology. 5th Edition. Churchill Livingstone; 2003.

10. Trigg ME, Sather HN, Reaman GH, Tubergen DG, Steinherz PG, Gaynon PS, Uckun FM, Denman Hammond G. Ten-year survival of children with acute lymphoblastic leukemia: a report from the Children's Oncology Group. Leuk Lymphoma. 2008;49(6):1142-1154.

11. Bostrom BC, Sensel MR, Sather HN, Gaynon PS, La MK, Johnston K, Erdmann GR, Gold S, Heerema NA, Hutchinson RJ, Provisor AJ, Trigg ME; Children's Cancer Group. Dexamethasone versus prednisone and daily oral versus weekly intravenous mercaptopurine for patients with standard-risk acute lymphoblastic leukemia: a report from the Children's Cancer Group. Blood 2003;101(10):3809-3817.

12. Schacke H, Döcke WD, Asadullah K. Mechanisms involved in side effects of glucocorticoids. Pharmacology\&Therapeutics 2002;96:23-43.

13. Sartori TM, Maurizio PG, Sara P, Ugolino L, Annalisa A, Panagiotis T, Massimo F, Antonio G. Relation between long-term steroid treatment after heart transplantation, hypofibrinolysis and myocardial microthombi generation. J Heart Lung Transplant 1999;18:693-700.

14. Sholter DE, Armstrong PW. Adverse effects of corticosteroids on the cardiovascular system. Can J Cardiol 2000;16:505-511.

15. Kelly JJ, Mangos G, Williamson PM, Whitworth
JA. Cortisol and hypertension. Clin Exp Pharmacol Physiol 1998;25:51-56.

16. Sato A, Fundder JW, Okubo M, Kubota E, Saruta T. Glucocorticoids-induced hypertension in the elderly. Relation to serum calcium and family history of essential hypertension. Am J Hypertension 1995;8:823-828.

17. Bogdanović i saradnici. Smernice za dijagnozu, ispitivanje $\mathrm{i}$ lečenje visokog krvnog pritiska kod dece i adolescenata. Beograd: Institut za zaštitu majke i deteta Srbije „Dr Vukan Čupić“; 2010 (Serbian).

18. Yang L, Panetta JC, Cai X, Yang W, Pei D, Cheng C, Kornegay N, Pui CH, Relling MV. Asparaginase may influence dexamethasone pharmacokinetics in acute lymphoblastic leukemia. J Clin Oncol. 2008;26:1932-1939.

19. Nobuko Hijiyaa and Inge M. van der Sluisb. Asparaginase-associated toxicity in children with acute lymphoblastic leukemia. Leukemia \& Lymphoma 2016;57(4):748-757.

20. Oktay Tacara, Pornsak Sriamornsakb,c and Crispin R. Dassa. Doxorubicin: an update on anticancer molecular action, toxicity and novel drug delivery systems. Journal of Pharmacy and Pharmacology 2013; 65:157-170.

21. Chan JD. Pharmacokinetic drug interactions of vinca alkaloids: summary of case reports. Pharmacotherapy 1998;18:1304-7.

22. Thomas DA, Kantarjian HM, Stock W, Heffner LT, Faderl S, Garcia-Manero G, Ferrajoli A, Wierda W, Pierce S, Lu B, Deitcher SR, O'Brien S. Phase 1 multicenter study of vincristine sulfate liposomes injection and dexamethasone in adults with relapsed or refractory acute lymphoblastic leukemia. Cancer. 2009;115(23):5490-8.

23. Aguayo A, Cortes J, Thomas D, Pierce S, Keating $\mathrm{M}$, Kantarjian $\mathrm{H}$. Combination therapy with methotrexate, vincristine, polyethylene-glycol conjugated-asparaginase, and prednisone in the treatment of patients with refractory or recurrent acute lymphoblastic leukemia. Cancer. 1999 Oct $1 ; 86(7): 1203-9$

24. Shuster J. Psychiatric complicatons of corticosteroids. Nursing 1999;29-31.

25. Sutor B, Wells LA, Rummans TA. Steroid-induced depressive psychosis responsive to electroconvulsive therapy. Convels Ther 1996;12:104-107.

26. Von der Weid N, Mosimann I, Hirt A, Wacker P, Nenadov Beck M, Imbach P, Caflisch U, Niggli $F$, Feldges A, Wagner HP. Intellectual outcome in children and adolescents with acute lymphoblastic leukaemia treated with chemotherapy alone: age-and sex-related differences. Eur J Cancer 2003;39(3):359-365.

27. Langer $\mathrm{T}$, Martus $\mathrm{P}$, Ottensmeier $\mathrm{H}$, Hertzberg H, Beck, JD, Meier W. CNS late-effects after ALL 
therapy in childhood, part III: neuropsychological performance in long-term surviviors of childhood ALL: impairments of concentration, attention, and memory. Med Pediatr Oncol 2002;38(5):320-328.

28. Brown RT, Madan-Swain A, Walco GA, Cherrick $\mathrm{I}$, levers CE, Conte PM, Vega R, Bell B, Lauer SJ. Cognitive and academic late effects amoung children previously treated for acute lymphocytic leukemia receiving chemotherapy as CNS prophylaxis. J Pediatr Psychol 1998;Oct;23(5):333-340.

29. Danilczuk Z, Ossowska G, Lupina T, Cieslik K, Zebrowska-Lupina I. Effect of NMDA receptor antagonists on behavioral impairment induced by chronic treatment with dexamethasone. Pharmacol Rep. 2005;57(1):47-54.

30. Richardson CT. Pathogenic factors in peptic ulcer disease. Am J Med 1985;79:1-7. 


\section{Sigurnost i tolerancija primene visokih doza glukokortikoida}

Branislava D. Rakić ${ }^{1,2}$, Jovanka L. Kolarović ${ }^{3}$, Nada V. Konstantinidis ${ }^{3}$, Velibor S. Čabarkapa ${ }^{4}$, Milan B. Ubavić 2 , Ana J. Sabo ${ }^{5}$, Aleksandar L. Raškovićs

${ }^{1}$ Medicinski fakultet, Zavod za Farmaciju, Univerzitet u Novom Sadu, Srbija

${ }^{2}$ Farmaceutski fakultet Novi Sad, Univerzitet Privredna Akademija u Novom Sadu, Srbija

${ }^{3}$ Instutut za zdravstvenu zaštitu dece i omladine Vojvodine, Novi Sad, Srbija

${ }^{4}$ Medicinski fakultet, Zavod za Patofiziologiju, Univerzitet u Novom Sadu, Novi Sad, Srbija

${ }^{5}$ Medicinski fakultet, Zavod za Farmakologiju, toksikologiju i kliničku farmakologiju, Univerzitet u

Novom Sadu, Srbija

\section{KRATAK SADRŽAJ}

Uvod: Terapija akutne limfoblastne leukemije, obuhvata primenu visokih doza glikokortikoida (prednizona i deksametazona), koji zbog svog lifocitolitičkog delovanja, značajno povećavaju uspeh terapije.

Cilj: Cilj rada je da se ispita pojava, vrsta i intenzitet neželjenih efekata visokih doza prednizona i deksametazona kod dece obolele od akutne limfoblastne leukemije.

Materijal i metode: $U$ prospektivnom ispitivanju, analizirane su istorije bolesti dece obolele od akutne limfoblastne leukemije koja su lečena u Institutu za zdravstvenu zaštitu dece i omladine Vojvodine u Novom Sadu od decembra 2010. godine do oktobra 2014. godine. Ispitivanje je obuhvatilo 18 pacijenata, uzrasta od 2 do 15 godina. Rezultati: Hiperglikemija se javila kod 89\% pacijenta lečenih prednizonom i $61 \%$ pacijenta lečenih deksametazonom. Za regulisanje visoke glikemije, preko $10 \mathrm{mmol} / \mathrm{l}$, kod $11 \%$ pacijenata primenjen je insulin. Hipertenzija se javila kod $28 \%$ pacijenta lečenih prednizonom i deksametazonom. Antihipertenzive je bilo neophodno primeniti kod $17 \%$ pacijenata. Hipokalijemija i hipokalcijemija su bile izraženije posle primene prednizona u odnosu na deksametazon. Deksametazon je izazvao depresivno ponašanje, a potom agitiranost kod $11 \%$ pacijenta.

Zaključak: Neželjena delovanja deksametazona i prednizona, primenjenih u visokim dozama kod dece obolele od akutne limfoblastne leukemije su bila poznata, očekivana i reverzibilna. Zabeležene neželjene reakcije su se najčešće povlačile spontano, ili posle kratkotrajne simptomatske terapije.

Ključne reči: prednizon, deksametazon, akutna limfoblastna leukemija, neželjena delovanja, deca 